\title{
Experience of spouses of women with breast cancer: an integrative literature review
}

\author{
EXPERIÊNCIA DOS CÔNJUGES DE MULHERES COM CÂNCER DE MAMA: UMA \\ REVISÃO INTEGRATIVA DA LITERATURA
}

\section{EXPERIENCIA DE LOS CÓNYUGES DE MUJERES CON CÁNCER DE MAMA: UNA REVISIÓN INTEGRADORA DE LA LITERATURA}

\section{Rhyquelle Rhibna Neris ${ }^{1}$, Anna Cláudia Yokoyama dos Anjos²}

\begin{abstract}
Objective: To gather, to characterize, to analyze, to synthesize and to integrate primary studies that addressed the experiences of spouses / husbands / partners of women with breast cancer, presenting the current state of knowledge. Method: Integrative literature review carried out in the databases of VHL, PubMed, CINHAL e SciELO. Results: The sample consisted of eight studies published between 20002012 , which pointed to the experiences of the involvement and the care of the husbands towards their ill wives. Conclusion: This study highlights the need for attention and assistance to those spouses, as well as guidance and education to exercise the care the same way as the health staff has done with women. Furthermore, it emphasizes the importance of further studies in order to deepen the knowledge on this topic, and thus, improve the care with better scientific basis.
\end{abstract}

\section{DESCRIPTORS}

Breast neoplasms

Spouses

Family

Family relations

Oncology nursing

Review

\section{RESUMO}

Objetivo: Reunir, caracterizar, analisar, sintetizar e integrar estudos primários que abordaram as experiências dos cônjuges/ esposos/parceiros de mulheres com câncer de mama, apresentando o estado atual do conhecimento. Método: Revisão integrativa da literatura realizada nas bases de dados BVS, PubMed, CINHAL e SciELO. Resultados: A amostra foi composta por oito estudos, publicados no período de 2000 a 2012, que apontaram para experiências do envolvimento e cuidado dos maridos em relação às esposas adoecidas. Conclusão: Evidencia-se a necessidade de atenção e de assistência para com esses cônjuges, assim como orientação e educação para o exercício do cuidado e como tem sido realizado pela equipe de saúde para com essas mulheres. Ressalta-se, ainda, a importância de novos estudos, a fim de aprofundar o conhecimento sobre essa temática e, assim, aprimorar a assistência com melhor embasamento científico.

\author{
DESCRITORES \\ Neoplasias da mama \\ Cônjuges \\ Família \\ Relações familiares \\ Enfermagem oncológica \\ Revisão
}

\begin{abstract}
RESUMEN
Objetivo: Reunir, caracterizar, analizar, sintetizar e integrar estudios primarios que abordaron las experiencias de los cónyuges/esposos/compañeros de mujeres con cáncer de mama, presentando el estado actual del conocimiento. Método: Revisión integradora de la literatura realizada en las bases de datos BVS, PubMed, CINHAL y SciELO. Resultados: La muestra estuvo compuesta de ocho estudios, publicados en el período de 2000 a 2012, que señalaron las experiencias de la involucración y el cuidado de los maridos con relación a sus esposas enfermas. Conclusión: Se evidencia la necesidad de atención y asistencia a esos cónyuges, así como la orientación y educación para el ejercicio del cuidado, como está realizando el equipo de salud con respecto a las mencionadas mujeres. Se subraya igualmente la importancia de nuevos estudios, a fin de profundizar el conocimiento acerca de esa temática y, de ese modo, perfeccionar la asistencia con mejor fundamento científico.
\end{abstract}

\author{
DESCRIPTORES \\ Neoplasias de la mama \\ Esposos \\ Familia \\ Relaciones familiares \\ Enfermería oncológica \\ Revisión
}

\footnotetext{
${ }^{1}$ Nursing Undergraduate Student, Faculty of Medicine, Universidade Federal de Uberlândia, Uberlândia, MG, Brazil. ${ }^{2}$ Adjunct Professor, Nursing Undergraduate Course, Faculty of Medicine and Coordinator of the Multidisciplinary Residency Program Attention in Oncology, Universidade Federal de Uberlândia. Uberlândia, MG, Brazil.
} 


\section{INTRODUCTION}

Breast cancer is the most common cancer in women and the fifth leading cause of cancer death in general (458,000 deaths). In 2009, deaths from breast cancer ranked first in Brazil with $15.3 \%$ of all cases. For the year 2012, 52,680 new cases that represented an incidence rate of 52.5 cases per 100,000 women were estimated ${ }^{(1)}$.

The natural process of diseases like breast cancer interferes greatly and directly in the physical, emotional and social conditions of women, which causes them to fear the disease and all the factors involved in the diagnosis, treatment and rehabilitation process ${ }^{(2)}$.

In face of the experiences that affect women with breast cancer, they may have difficulties in social and family relationships. It is amidst this complex scenario that day by day the family has acquired increased importance, with a significant collaborative role for coping with the disease ${ }^{(3)}$.

Within the household context, the spouse of the woman with breast cancer is a family member that stands out. They see cancer as a threat to the life of their partners, and like them, may not have sufficient and appropriate emotional resources to cope with the disease ${ }^{(4)}$, they may feel hopelessness, helplessness, restlessness and fear, among many other possible feelings that affect their own lives, the comfort, support and care to women, as well as the family and emotional relationships ${ }^{(5)}$. The spouses cannot be excluded from the context of care, on the contrary, they should be seen as people who need to receive assistance, support and to share their doubts, fears, anxieties and uncertainties ${ }^{(4)}$.

It is often perceived that the care and concern of health professionals who deal with breast cancer are preferentially directed to women affected by cancer. Thus, many times, the relationships of these women with other members of their families, and particularly with their companion go unnoticed ${ }^{(6)}$.

When experiencing cancer in their wives, the spouses often become fragile. They fear not being able to support and provide proper care, to bear the concrete loss of their women, and to go through the mourning. Amid these new situations, as well as the needs they generate, they are in need of help, requiring their inclusion as a care target by the health services. The same way as women are placed in support groups, these partners should be similarly assisted because it is necessary that they feel supported in their psychosocial needs, empowered and educated about the disease and treatment ${ }^{(4,7)}$.

Thus, this literature review was proposed aiming at bringing together, characterizing, evaluating and integrating primary studies that examined the experiences of husbands of women with breast cancer. The study presented the current state of knowledge seeking to expand the knowledge and the best scientific basis for the practice of targeted assistance to the partner.

\section{METHOD}

It is an integrative review of national and international literature that included the analysis of results of relevant studies that can provide support for decision making and the improvement of clinical practice ${ }^{(8)}$. The integrative review provides a synthesis of the state of knowledge of a particular theme, in addition to identifying gaps in knowledge that need to be filled with new studies. This research method allows to gather and synthesize multiple published studies, in addition to enabling general conclusions about a particular area of study ${ }^{(9)}$.

Six steps were used to conduct this integrative review, namely: identification of the theme and formulation of the guiding question; literature search and careful selection of studies; categorization of the studies retrieved; analysis of the studies included; interpretation of results and comparisons to other studies; report of the review and synthesis of knowledge evidenced in the studies ${ }^{(10)}$. In order to meet the study goals, the guiding question was defined: what has been investigated and published in the scientific community about the experiences of spouses of women with breast cancer?

The sample was composed of national and international scientific articles developed by healthcare professionals who investigated the spouses/partners of women with breast cancer. The literature survey was retrieved in the following databases: PUBMED (US National Library of Medicine), $\mathrm{Cl}$ NAHL (Cumulative Index to Nursing and Allied Health Literature), PsycolNFO - database of the American Psychological Association (APA), in the Research Portal of the Virtual Health Library (VHL) and Scientific Electronic Library Online (SciELO).

The searches in the PUBMED, CINAHL, PsycINFO and VHL databases were carried out in May and June 2013, and, in the SciELO database, they were done in February 2014. All the searches were done through the search strategy combination of the Health Sciences Descriptors (DeCS): breast neoplasms / neoplasias da mama, qualitative research / pesquisa qualitativa, family/familia, spouses/cônjuge, and the keyword breast cancer, linked by the Boolean operators AND and OR (Table 1). The PsycINFO database has its own descriptors, but the terms corresponded to the DeCS.

The established inclusion criteria were the following: qualitative primary research, available online, in the format of articles, in Portuguese, English or Spanish, and focused on the experience of spouses of women with breast cancer. The articles not related to the proposed theme that were not full text ones, free and available online in electronic databases, published in languages other than Portuguese, English or Spanish, and quantitative studies, were excluded. Articles repeated in different databases were considered only once. After reading the titles and abstracts of 304 initially retrieved studies, observing the 
established inclusion and exclusion criteria, a final sample of eight studies was obtained.

An instrument developed and validated by Ursi ${ }^{(11)}$ and adapted for this study was used for characterization and data collection related to the methodology and results.

In order to obtain a thorough analysis of the contents of the studies, the information was collected from the complete reading of the eight articles included. First, information was characterized according to the following: database where they were indexed, titles of articles and journals, authors, country, language, year of publication, host institution, professional area of authors, publication design (Table 2). The identification of those studies is ar- ranged in numerical form, thus making their location easy.

Subsequently, the aims, the methodological aspects and results of studies were verified. In Table 3, the selection and the characterization process of the participants of the studies and the outcomes were presented. Afterwards, the findings of the results in relation to the goals of the studies were analysed and then grouped into themes for discussion.

\section{RESULTS}

Chart 1 shows the search strategy combination of the estabilished methodological terms for qualitative research and their results, respecting the use of appropriate terms to the databases.

Chart 1 - Results of the search done in the databases, results of studies included and excluded in the review - Uberlândia, MG, 2013

\begin{tabular}{|c|c|c|c|c|}
\hline Database & Terms in Health Sciences (DeCS) & Results of search & Studies Excluded & $\begin{array}{c}\text { Studies included in } \\
\text { the Review }\end{array}$ \\
\hline CINAHL & $\begin{array}{l}\text { Breast cancer AND qualitative AND studies } \\
\text { AND family AND spouse }\end{array}$ & 20 & 16 & 4 \\
\hline \multirow{2}{*}{ VHL } & $\begin{array}{c}\text { Neoplasias da mama AND cônjuges AND } \\
\text { pesquisa qualitativa OR família }\end{array}$ & 181 & 178 & 3 \\
\hline & $\begin{array}{c}\text { Neoplasias da mama AND cônjuges AND } \\
\text { pesquisa qualitativa AND família }\end{array}$ & 3 & 3 & 0 \\
\hline PUBMED & $\begin{array}{c}\text { Breast neoplasms OR cancer AND } \\
\text { qualitative studies OR studies family AND } \\
\text { spouses }\end{array}$ & 24 & 23 & 1 \\
\hline \multirow{2}{*}{ PsycINFO } & $\begin{array}{l}\text { Breast neoplasms AND family AND } \\
\text { qualitative research AND spouses }\end{array}$ & 0 & 0 & 0 \\
\hline & $\begin{array}{l}\text { Breast neoplasms AND family OR } \\
\text { qualitative research AND spouses }\end{array}$ & 75 & 75 & 0 \\
\hline \multirow{3}{*}{ SciELO } & $\begin{array}{l}\text { Breast neoplasms OR breast cancer AND } \\
\text { qualitative studies AND spouses AND family }\end{array}$ & 0 & 0 & 0 \\
\hline & $\begin{array}{l}\text { Breast neoplasms AND breast cancer AND } \\
\text { qualitative studies AND spouses AND family }\end{array}$ & 1 & 1 & 0 \\
\hline & $\begin{array}{l}\text { Câncer de mama AND cônjuges AND } \\
\text { família OR pesquisa qualitativa }\end{array}$ & 0 & 0 & 0 \\
\hline \multicolumn{2}{|c|}{\begin{tabular}{|l|} 
Total of Study \\
\end{tabular}} & 304 & 296 & 8 studies \\
\hline
\end{tabular}

After carefully observing the focus of the studies and the inclusion and the exclusion criteria of this review, three articles from VHL, one (1) from PUBMED, four from CINAHL, and none from the PsycINFO database were included. The articles from PsicINFO did not meet the goals or were not focused on the study of the husband only. Thus, 16 articles from CINAHL, 181 from VHL, 23 from PUBMED, 75 from PsycINFO and one from the SciELO were excluded from this review, amounting to 296 articles, as shown in
Chart 1. An article was selected in the SciELO database, but it had already been selected in VHL, thus the decision was to keep it at the base where it was first found.

Part of the results is presented in Chart 2, which characterizes the studies of this review. The eight articles were published between 2000 and 2012; an interval of time was not established seeking to gather a higher number of publications. They are nursing and medicine areas journals.

Chart 2 - Title of article, journal title, country, year, design/number of participants - Uberlândia, MG, 2013 padronizar format dos intervalos

\begin{tabular}{|c|c|c|}
\hline Title of Articles & $\begin{array}{c}\text { Country } \\
\text { Year }\end{array}$ & Design/Number of participants \\
\hline $\begin{array}{l}\text { E1- Psychosocial Perspectives of the Partners } \\
\text { of Breast Cancer Patients Treated With a } \\
\text { Mastectomy }{ }^{(12)} \text { (Cancer Nursing) }\end{array}$ & $\begin{array}{c}\text { BRAZIL } \\
2008\end{array}$ & $\begin{array}{l}\text { Qualitative study. Method of narrative analysis. Theoretical framework not } \\
\text { mentioned. Interviews with selected husbands; duration between } 30-60 \text { minutes. } \\
\text { Data collection site and number of interviews with each participant not informed. } \\
\text { Sample of } 17 \text { spouses. }\end{array}$ \\
\hline $\begin{array}{l}\text { E2- Coming to grips with Breast Cancer: The } \\
\text { spouse's Experience with His Wife's First Six } \\
\text { Months }^{(13)} \text { (Journal of Psycosocial Oncology) }\end{array}$ & $\begin{array}{l}\text { USA } \\
2010\end{array}$ & $\begin{array}{l}\text { Qualitative study. Theoretical framework not mentioned. Data collection in the } \\
\text { homes of participants. Confidential interviews lasting between } 20-45 \text { minutes, audio } \\
\text { recorded. Number of interviews with each participant not informed. Sample of } 48 \\
\text { spouses. }\end{array}$ \\
\hline
\end{tabular}




\begin{tabular}{|c|c|c|}
\hline Title of Articles & $\begin{array}{l}\text { Country } \\
\text { Year }\end{array}$ & Design/Number of participants \\
\hline $\begin{array}{l}\text { E3 - Engaging Hope: The Experiences of Male } \\
\text { Spouses of Women With Breast Cancer }{ }^{(14)} \\
\text { (Oncology Nurse Forum) }\end{array}$ & $\begin{array}{l}\text { CANADA } \\
2012\end{array}$ & $\begin{array}{l}\text { Qualitative, descriptive and interpretative study. Theoretical framework not mentioned. } \\
\text { Open-ended, tape-recorded telephone interviews. The participants was interviewed } \\
\text { twice. The authors did not describe the duration of the interviews. Sample of } 11 \text { spouses. }\end{array}$ \\
\hline $\begin{array}{l}\text { E4 - Men's Perspectives on Individual and } \\
\text { Family Coping With Their Wives'Breast } \\
\text { Cancer and Chemotherapy }{ }^{(15)} \text { (Western Journal } \\
\text { of Nursing Research) }\end{array}$ & $\begin{array}{l}\text { USA } \\
2000\end{array}$ & $\begin{array}{l}\text { Qualitative study. Theoretical framework not mentioned. Semi-structured interviews } \\
\text { carried out in places chosen by the participants, lasting } 1-2 \text { hours; the authors did } \\
\text { not describe the number of interviews conducted. Sample of } 10 \text { spouses. }\end{array}$ \\
\hline $\begin{array}{l}\text { E5 - Men's Sexual Issues After Breast Cancer } \\
\text { in Their Wives }{ }^{(16)} \text { (Cancer Nursing) }\end{array}$ & $\begin{array}{l}\text { IRAN } \\
2012\end{array}$ & $\begin{array}{l}\text { Qualitative research, theoretical framework of grounded theory. In-depth interviews, } \\
\text { recorded, and conducted face to face with the participants, lasting } 30-80 \text { minutes. } \\
\text { The location and the number of interviews carried out were not described. Sample } \\
\text { of } 18 \text { spouses. }\end{array}$ \\
\hline $\begin{array}{l}\text { E6 - Suporte social na reabilitação da mulher } \\
\text { mastectomizada: o papel do parceiro sexual }{ }^{(5)} \\
\text { (Journal of São Paulo University of School of } \\
\text { Nursing) }\end{array}$ & $\begin{array}{l}\text { BRAZIL } \\
2004\end{array}$ & $\begin{array}{l}\text { Qualitative research. Theoretical framework not mentioned. The data collection } \\
\text { process was not described by the authors, who quoted that only semi-structured } \\
\text { interviews were carried out. Sample of nine spouses. }\end{array}$ \\
\hline $\begin{array}{l}\text { E7 - Percepção de cônjuges de mulheres } \\
\text { mastectomizadas com relação à convivência pós- } \\
\text { cirurgia }^{(17)} \text { (Journal of São Paulo University of } \\
\text { School of Nursing) }\end{array}$ & $\begin{array}{l}\text { BRAZIL } \\
2010\end{array}$ & $\begin{array}{l}\text { Qualitative research. Theoretical framework not mentioned. Semi-structured interviews } \\
\text { conducted in the residence of the participants recorded on tape. The authors did not } \\
\text { describe the number of interviews carried out. Sample of five spouses. }\end{array}$ \\
\hline $\begin{array}{l}\text { E8 - A participação dos companheiros no } \\
\text { diagnóstico e no tratamento do câncer de } \\
\text { mama de suas mulheres }{ }^{(7)} \text { (Brazilian Journal of } \\
\text { Mastology) }\end{array}$ & $\begin{array}{l}\text { BRAZIL } \\
2006\end{array}$ & $\begin{array}{l}\text { Descriptive, analytical, qualitative research with psychoanalytic theoretical } \\
\text { framework. Semi-structured interviews carried out in two teaching hospitals. } \\
\text { Spouses were interviewed in three moments, not described if they were recorded. } \\
\text { Sample of } 12 \text { spouses. }\end{array}$ \\
\hline
\end{tabular}

Figure 1 provides the percentage of studies/year between $2000-2012$. Note that $25 \%$ of the studies were published in 2012 alone.

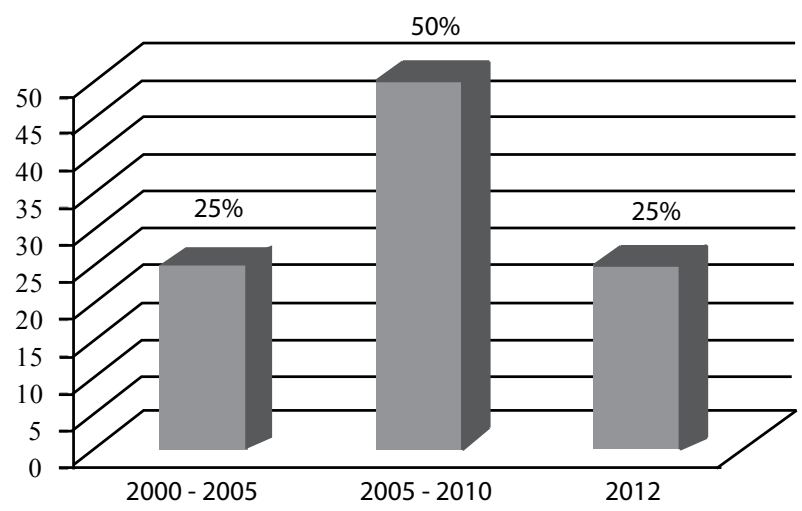

Figure 1 - Percentage of studies per year - Uberlândia, MG, 2013

As for language, $63 \%$ (five articles) of the studies were published in English and 37\% (three articles), in Portuguese. Although articles in Spanish could be used in the sample meeting the search criteria, no study in this language addressing the theme was indexed in the databases.

Regarding the professional area of authors, seven studies were developed by nursing professionals and only one by medical professionals.

In relation to the study designs that comprised the sample of this review, considering the aim of getting to know the spouses' experience, only studies of the qualitative nature were selected.

Chart 3 shows the eight studies included in the review. Four (E4, E6, E7 and E8) described semi-structured interviews as the resource for data collection. Two articles
(E1 and E5) described in-depth interviews, which is very close to the psychoanalytic nature. Through this design, motivations, desires, conflicts, fears, and also personality conflicts are known ${ }^{(18)}$. It was also found that two studies (E2 and E3) did not describe the process of data collection.

As to the aims established by the authors of the studies in this review, a description that is clear and easy to understand was observed. Three authors established the goals of exploring the experience of the spouses in face of the wives' breast cancer (E2, E3 and E4), another article described the perception of the spouses in face of their wives' mastectomy (E7), other authors aimed at describing the psychosocial effects and the mastectomy mastectomy from the husbands' point of view and their perspective of this experience (E1), one article aimed at analyzing the participation of partners in the diagnosis and treatment of breast cancer (E8), another identified the type of social support offered by sexual partners of women with breast cancer (E6), and finally, one study explored the sexual concerns of the husbands (E5).

Regarding the number of the study participants and selection process, great variation was observed, with quantitative from five to 48 spouses. As for the selection, three studies reported that the participants were selected from their wives' procedures and or health care appointments, considering that a previous contact was established with patients with breast cancer, and then, with their partners (E1, E6 and E7); two studies described that the sample consisted of a subsample of larger studies, but did not bring details about the participants selection process (E2 and E4), and finally, the remaining three studies did not describe the method used for selecting the participants (E8, E5 and E3). 
The theoretical frameworks used by the authors for the analysis and discussion of data were the following: the narrative analysis used to recap past experience through the combination of verbal sequence of sentences with the sequence of events that actually occurred ${ }^{(19)}$. The psychoanalytic theoretical framework that seeks to understand the human beings in their wholeness, drawing attention both to their physical aspects and their feelings and emotions ${ }^{(20)}$. The theoretical framework of grounded theory aimed at understanding the reality from the perception or meaning that a certain context or object has to the person, generating knowledge, increasing understanding, and providing a meaningful guide to the action ${ }^{(21)}$.

Chart 3 - Selection and characterization of participants according to the type of research and outcomes - Uberlândia, MG, 2013

\begin{tabular}{|c|c|c|}
\hline \multicolumn{2}{|r|}{ Selection and caracterization of participants of studies } & Outcomes \\
\hline E1 & $\begin{array}{l}\text { Initial contact with } 30 \text { women during the post-mastectomy control } \\
\text { appointment in the outpatient clinic. Among the } 30 \text { contacted women, } 10 \\
\text { declined the invitation; among the } 20 \text { contacted husbands, three refused to } \\
\text { participate. Sample of } 17 \text { men; aged } 54-84 \text {. Religion / belief: } 10 \text { Catholics, } \\
\text { four (4) Evangelicals, two (2) Presbyterians and one (1) Jehovah's Witness. } \\
\text { Characteristics of the population not fully described (educational level, } \\
\text { socioeconomic status, among others). }\end{array}$ & $\begin{array}{l}\text { Positive changes in the relationship. Impaired sexual activity } \\
\text { after breast cancer. Change in the family routine, with the } \\
\text { men taking over household chores. Fear of the death of their } \\
\text { wives. Religious support during the illness because they } \\
\text { complained about the lack of focus of the health care team } \\
\text { toward the family of the woman with cancer. }\end{array}$ \\
\hline E2 & $\begin{array}{l}\text { Husbands of women diagnosed with breast cancer in the early stages (stage } \\
0-2 \text { ), in the previous six months, and in treatment at the time of the study. The } \\
\text { subsample of a larger randomized study was used; } 48 \text { men participated, aged } \\
31-68 \text {, and } 87 \% \text { of them had university degree. Characteristics of the population } \\
\text { not fully described (religion, socioeconomic status, among others). }\end{array}$ & $\begin{array}{l}\text { Impaired sexual activity of the couple after cancer; reports } \\
\text { of role reversal in the family routine, and relationship } \\
\text { changes with positive and negative aspects. Positive feelings } \\
\text { such as hope of cure for the wives' cancer; negative aspects: } \\
\text { the husbands hid their real feelings from the families and the } \\
\text { fear of losing their partners. }\end{array}$ \\
\hline E3 & $\begin{array}{l}\text { Spouses of women with breast cancer were invited to participate in the study. } \\
\text { Participants provided the contact (phone / email) of the researchers to other } \\
\text { spouses. Sample of } 11 \text { spouses aged } 36-76 \text {, average age: } 55 \text {, and with an average } \\
\text { of } 17 \text { years of study. Other population characteristics not described by the authors. }\end{array}$ & $\begin{array}{l}\text { Religious support is important throughout the illness; positive } \\
\text { changes in the couple's relationship. Feelings of family } \\
\text { preservation; it was observed that the spouses did not show } \\
\text { their real feelings of fear; changes in the family household } \\
\text { chore routine was necessary with the men taking it over. }\end{array}$ \\
\hline E4 & $\begin{array}{l}\text { Partners of women diagnosed with cancer in the two previous years, and treated } \\
\text { with chemotherapy. Recruited through the participation in a larger study; the } \\
\text { selection was of the snowball type - participating spouses identified other } \\
\text { spouses. Sample of } 10 \text { spouses, aged } 39-58 \text {, average age: } 47 \text {. The authors did } \\
\text { not describe the population characteristics (level of education, socioeconomic } \\
\text { status, among others). }\end{array}$ & $\begin{array}{l}\text { A positive change in the marital relationship was reported, but } \\
\text { the cancer impaired the couple's sexual activity. There was also } \\
\text { a reversal of roles within the family, and the spouse takes over } \\
\text { the household chores. Feelings of hope of a cure for their wives' } \\
\text { cancer, and fear of the partner's death were described. }\end{array}$ \\
\hline E5 & $\begin{array}{l}\text { Partners of women with breast cancer were intentionally selected in cancer } \\
\text { treatment centers or specialized clinics in Iran. A sample of } 18 \text { spouses, aged } \\
\text { 33-70, average age: } 51 \text {. All spouses were Shiite Muslims, five (5) participants } \\
\text { were employed, eight ( } 8 \text { ) unemployed and five (5) were retired. The level of } \\
\text { education was not described by the authors. }\end{array}$ & $\begin{array}{l}\text { Positive changes in the marital relationship, with reports } \\
\text { of greater union after cancer; couple's sexual activity was } \\
\text { impaired. }\end{array}$ \\
\hline E6 & $\begin{array}{l}\text { Spouses of female participants of a Rehabilitation Center were invited to participate } \\
\text { in the study. The sample consisted of nine (9) partners of women with breast } \\
\text { cancer. No description of any socioeconomic characteristics of the population. }\end{array}$ & $\begin{array}{l}\text { Change in the family dynamics, with the men taking over } \\
\text { housework and children care; improvement in the marital } \\
\text { relationship, however, with impaired sexual activity. }\end{array}$ \\
\hline E7 & $\begin{array}{l}\text { Spouses of women affected by breast cancer, with regular attendance at the } \\
\text { Association of Mastectomized Women (AMW). In total, five (5) spouses aged } 45- \\
56 \text { agreed to participate in the study; socioeconomic status of low income; four (4) } \\
\text { spouses had minimal schooling, and one (1) university degree. Other population } \\
\text { characteristics, such as religion and socioeconomic status were not described. }\end{array}$ & $\begin{array}{l}\text { Religious support during the process of coping with the } \\
\text { disease, positive feelings about the healing of their wives; } \\
\text { reversal of roles in the family routine and household chores, } \\
\text { and improvement in the marital relationship after diagnosis. }\end{array}$ \\
\hline E8 & $\begin{array}{l}\text { Partners of women with breast cancer randomly selected. A sample of } 12 \\
\text { participants. The authors did not describe characteristics of the population, such } \\
\text { as socioeconomic status, religion and education. }\end{array}$ & $\begin{array}{l}\text { Sadness, fear of losing their wives and concealment of the } \\
\text { real feelings on breast cancer. }\end{array}$ \\
\hline
\end{tabular}

The age of the spouses participating in the study was quite broad, with a higher concentration of 50-year-olds. Other features related to the study participants' sociodemographic data were not described by the authors; only two studies reported the belief / religion of the participants (E1 and E5); and a study (E5) described that $100 \%$ of its participants were Shiite Muslims.

None of the analyzed articles has proposed nor used intervention methods. The studies were focused on knowing/understanding the experience/perception of the spouses in face of their wives' breast cancer.

Among the eight articles analyzed in this review, five of them predict practical applicability (E1, E2, E3, E4 and E5).
The one that stood out was the provision of whole care by a health team targeting the entire family, and thus, the spouses, not only the cancer patients. Another highlight of practical applicability found in four of the studies (E2, E3, E4, E5) was the creation of support groups for the spouses, where they can meet other spouses and share their fears and anxieties.

Throughout the analysis of the study results, underlying categories and/or themes were identified. They stood out due to the similarity and relevance given by the authors, being found in several of the studies. Thus, the results of the articles that were part of this review were divided into eight categories and/or themes, as shown in Chart 4.
Experience of spouses of women with breast cancer: an integrative literature review Neris RR, Anjos ACY 
Chart 4 - Distribution of themes related to the investigation results of the articles in this review- Uberlândia, MG, 2013

\begin{tabular}{|c|l|c|}
\hline $\begin{array}{c}\text { Identification } \\
\text { number }\end{array}$ & \multicolumn{1}{|c|}{ Categories/ Themes } & \multicolumn{1}{|c|}{ Articles } \\
\hline 1 & $\begin{array}{l}\text { 'Changes in the relationship after breast cancer': } \\
\text { - Positive aspects } \\
\text { - Negative aspects }\end{array}$ & $\begin{array}{c}1,2,3,4,5, \\
6 \text { and } 7 \\
\text { and } 4\end{array}$ \\
\hline 2 & 'Impaired sexual activity & $1,2,4,5,6$ \\
\hline 3 & 'Spouses as "managers of the home"/ change in routine / care of children' & $1,2,4,6,7$ \\
\hline 4 & 'Hope / positive feelings about the cure of the disease' & $1,2,3,4,7$ \\
\hline 5 & 'Concealing / hiding real feelings' & $2,3,4,8$ \\
\hline 6 & 'Sadness and fear of losing the partner' & $1,2,4,8$ \\
\hline 7 & 'Religious support during the process of coping with the disease' & $1,3,7$ \\
\hline 8 & 'Lack of focus on the family' & 1,4 \\
\hline
\end{tabular}

In general, it is observed that most of the studies, i.e., five $(62.5 \%)$, approached 50 to $87.5 \%$ of the identified themes. The most frequently investigated topics were the following: theme 1: appeared in seven out of the eight studies, corresponding to $87.5 \%$; themes 2,3 and 4 : appeared in five (62.5\%) studies, respectively.

\section{1 - Changes in the relationship after breast cancer}

The diagnosis of breast cancer led to several changes in the couple's life, among which, one worth mentioning is the change in the marital relationship. Two kinds were found: either amounting to the positive aspects prior to the discovery of cancer or bringing conflict to the couple's relationship. Positive changes in the relationship after cancer was a theme found in the studies, except for E8. Spouses reported the strengthening of the existing love and the increase of unconditional support to their partners. In opposition to this first observation, where breast cancer has led to the couple's closeness, the E2 and E4 studies found the negative impacts of the illness on the couple's relationship; in this category, the cancer challenged and brought conflict to the relationship of some couples. The disease also had negative effects on the couple's communication. Spouses especially reported the difficulty in talking about breast cancer.

Still as part of this theme, the spouses' perceptions were identified in relation to the relationship with their wives, such as the strengthening of the bond of love, the perception of increased tenderness and a greater understanding. They also reported that they perceived themselves as important in their wives' process of coping with the disease (E7).

\section{2 - Impaired sexual activity}

The second category most frequently found in the speeches of the participants was present in the E1, E2, E4, E5, E6 and E7 studies, i.e., the decreased frequency of sexual intercourse due to breast cancer and its treatment. Despite this aspect, considered by many as negative, a change of focus in the marriage (quoting the participants) was identified, no longer focusing on the sexual aspect. Women were considered as the most important person in the husbands' lives. Thus, they were concerned about supporting them, assuming that breast cancer is considered a threatening disease.

\section{3 - Spouses as managers of the home / change in routine}

This theme, found in the results of E1, E2, E4, E6 and E7, showed that breast cancer changed the family dynamics and the roles of the family members in the studies included. Many times the spouses added to their work activities the responsibility of the household chores and the care of their wives.

In addition to the double or even triple shift, the spouses also reported efforts to be physically present and give emotional support causing them a great weariness.

There was an evident perception of the participating spouses about the necessity and importance of the wives in parenting. This comprehension made them grateful for acknowledging what the wives had already done. However, it also triggered feelings of fear and powerlessness in face of the possibility of the wife's absence (E7).

\section{4 - Hope/positive feelings about the cure of the wife's disease}

This theme was presented in the categories of the results of E1, E2, E3, E4 and E7. The spouses used hope and positivity as a way of coping with the suffering experienced from the moment of the diagnosis, throughout the treatment, reaching the rehabilitation phase or, sometimes, death. The authors also reported that many spouses kept hopeful as a way of supporting and understanding their wives.

\section{5 - Concealing / hiding real feelings}

This theme was found in E2, E3, E4 and E8. Spouses often hid their real feelings, demonstrating positivity and hope, as a way to protect their wives, children and, even themselves, from suffering. Many felt that demonstrating their feelings would be proof of their weakness in face of the disease.

\section{6 - Sadness and fear of losing the partner}

This was a very present theme identified in E1, E2, $\mathrm{E} 4$ and E8. After the diagnosis of their wives' breast neoplasms, there were mixed feelings involving the spouses, which can be attributed to the fact that cancer is still a disease very stigmatized by society, frequently associated 
with pain, suffering, disfigurement and death. Some of the common feelings experienced by spouses after their wives' diagnosis are shock, disbelief, denial, anger, guilt, depression, anxiety, uncertainty, despair, fear, loss of control and isolation (E2 and E4).

\section{7 - Religious support during the process of coping with the disease}

Theme found in three studies (E1, E3, and E7). Throughout the search of the cure of their wives' disease, the spouses clung to the faith in God as a spiritual basis for dealing with moments of great suffering. The statements here reported indicated that the faith and belief in God enabled the adjustment to the new situation and improved the coping ability for both the women and their partners.

The perceptions of the spouses on the importance of believing in God strengthened the hope and the understanding during the illness, and brought comfort to them in face of the difficult moments of sadness, uncertainty, fear and insecurity (E7).

\section{8 - Lack of focus on the family}

In the E1 and E4 studies, the lack of focus on the family was identified. It showed a gap between the treatment of women with breast cancer and their social and family context. The family is not included in the context of care by health professionals, and the focus turned solely to the woman with breast cancer, neglecting the social and family group to which she belongs.

\section{DISCUSSION}

The articles used in the review were published between 2000 and 2012. Prior to 2000, no study related to the topic and indexed in the investigated databases was found. $25 \%$ of the studies of this review were published in 2012. Compared to the period between 2000 and 2005, there was the same number of publications, however, in a time-period five times greater. Despite the increasing number of studies on the theme, the production of published studies is still small. No other literature review addressing this issue or any other similar one were found, highlighting once again the importance of this and of new studies.

Nursing was the field in which more studies were found. As the cancer treatment is of high complexity, it involves different therapeutic approaches, requiring interdisciplinary team performance. It is important to integrate professionals from other health areas in research on this theme, which should not be restricted only to nursing professionals.

The qualitative research methodology has given participants the chance of expressing their experiences, perceptions and meanings. The semi-structured and in-depth interviews and the focus groups were the most used tools for collecting data and turning them into scientific knowledge. The interview enables establishing an open relationship between the interviewer and the interviewee, in order for the dialogue to flow spontaneously, making the research rich in details, with no rupture between the project and the goals ${ }^{(17)}$. Therefore, the strategies defined for data collection of the studies in this review were found to be appropriate in relation to the methodology and aims proposed by the researchers.

Only three studies (E1, E5 and E8) mentioned and described the theoretical framework. In order to understand the experience of the participants, the use of the theoretical framework is extremely important in the development of a qualitative research. The correct analysis and interpretation of the collected data will only be appropriate depending on the correct choice of a theoretical framework that provides background and support. Thus, this important component of the research was underestimated in the majority of the studies included (E2, E3, E4, E6 and E7), making them weak from the theoreticalreflective point of view. Many studies published as results of qualitative research, in fact, used only techniques for collecting qualitative data (semi-structured interviews, focus groups, observation, among others) without bringing a theoretical framework for the analysis and the discussion of the data.

In general, the published studies presented limited information on the characteristics of the participants and the sociodemographic data, preventing a broadened knowledge, invalidating the standardization of the collected information, and the further analysis of features that may be related to the socioeconomic status itself, such as habits, risk factors, among other extremely important aspects in the study of populations, as the one chosen for this review: husbands of cancer patients.

The authors of the studies included presented several recommendations for the practice of care. The need to know the patient's family's routine was the one that stood out. The family is a valuable component in fighting the disease and the care for the rehabilitation of women with breast cancer, offering support and emotional, spiritual and biopsychological attention, having an important place in this process ${ }^{(22)}$. Thus, the need for involving the family in the care of this woman became evident, but the family, including the spouse, must feel strong and able to provide such care, receiving the suitable support and education to cope with the situation.

Therapeutic groups focused on the husband appeared as a prominent recommendation among the authors. This resource must be thought as a space for sharing and strengthening of those men who have been willing to be with their wives, but suffer for not being qualified or even strengthened to do so. Hence, by working with multiprofessionals and in a multidisciplinary way, the health
Experience of spouses of women with breast cancer: an integrative literature review Neris RR, Anjos ACY 
professionals shall seek strategies to enable this and other ways of providing for the husbands.

Throughout the findings, it was possible to identify the magnitude of the changes in the dynamics and in the personal life of the spouse, the family and also in the marital relationship. Moreover, the feelings that permeate the process of coping with the disease and the difficulties faced by these men to offer support and care. Often the roles carried out by the women prior to the illness are now taken over by the spouses.

Providing social support after the cancer diagnosis, and reducing the stress it causes are important tools for strengthening the bond between the couple, which are only achieved within a well-structured relationship or marriage. On the other hand, when there is a lack of structure in marital relations, the negative effects are reflected in the physical, social and emotional functions ${ }^{(23)}$. In many cases, cancer makes previously existing marital problems evident $^{(13)}$, even causing the breakup of the relationship/marriage. The literature describes the importance of a good communication in the marital relationship, since couples who do not communicate cannot maintain the much needed intimacy; without communication it is extinguished ${ }^{(24)}$

Due to the debilitating effects of the treatment of breast cancer for women, there is often a reversal of roles and routines concerning household chores. Changes become necessary in the family dynamics and with the husband taking over the role of the home manager. When women are diagnosed with breast cancer, especially in case of the surgical treatment - mastectomy -, a movement restriction of the upper limb was observed in most of them due to the axillary dissection on the side of the affected breast. Many times, the restriction may remain throughout the patient's life and not just temporarily. Thus, a readaptation of the already established family routine is needed, with the main focus on household chores that are culturally assigned to women ${ }^{(12)}$.

The development of coping strategies, such as positivity and hope of cure, helps and ensures the family protection. It also makes it possible for the women to find their motivation by means of the love cherished by their relatives, especially the spouses who are engaged in the process $^{(25)}$.

There are reports of the spouses hiding their feelings of fear as an attempt to protect their wives and families, but a clear communication between the couple and among the family members is essential. So that they can discuss their doubts, fears, anxieties and thus, go through a milder experience of the disease and treatment. Poor communication may impair coping, drive people away and make the course more painful. That sense of protection on behalf of the husbands can be justified due to the fact that cancer affects not only the women, but the family as a whole, especially the spouses ${ }^{(26)}$.
Studies have shown that the moments of greatest suffering for the spouses were in face of the breast cancer diagnosis, and when women underwent surgery as part of the treatment. However, the suffering is not restricted only to these two moments, but it lasts throughout the course, from the diagnosis up to the healing, the rehabilitation or the death ${ }^{(27)}$. These findings show that the health professionals are responsible for enlightening about the disease and the treatment. When instructed, the spouses feel more confident, less sad and less scared.

Faith was the main source of support and assistance mentioned by the spouses in times of difficulty during the cancer treatment of their wives. Faith enables a strengthening of understanding and hope, helping to overcome the challenge of facing the disease and the treatments, as well as providing better support to their partners. As the pain reduces, the hope of healing increases. The belief in God increases faith, trust in the healing and success at the end of the treatment. This bond to religion relieves the suffering and serves as a refuge $\mathrm{e}^{(2,6)}$

Among other findings, this review allowed to identify a major flaw in the context of assistance to women with breast cancer, which is the lack of focus on the family and spouse. In general, health professionals have focused their assistance only on the patient, forgetting that there is often a family that needs attention, education and care. The diagnosis of breast cancer affects the entire family that faces times of great suffering. Emotions get unbalanced with the news of cancer in a loved relative. Hence, more focus should be given to assist the family by answering questions, giving consistent information on the treatment and continuously developing a process of education for the care and health promotion.

The need for the health professionals to establish effective communication became evident, creating strong ties with the whole family, not only with the women. Offering comprehensive listening and continuous support should also be part of the care provided by the health team, as it may help patients and families to strengthen their ties and relationships, resolving conflicts and thus, minimizing suffering ${ }^{(12)}$.

\section{CONCLUSION}

The results of this review enabled to deepen the knowledge on such an important topic and cast a critical eye on the knowledge produced in the national and international literature on the experience of the spouse in face of his wife's breast cancer.

This review brought to light the existence of a significant gap in the care of women with breast cancer, since many relatives and spouses were not considered important components in this process. They were not included as participants and were neglected. As discussed 
throughout this review, the spouses also need care the same way as the women with cancer do. They need additional information about the illness of their wives, their treatment, and they need to receive attention to their emotional, social and sexual needs.

Given the importance of the theme, few studies have been found in the national and international literature addressing the experience of the spouses. This referred to the need of investing in research focused on this area.

\section{REFERENCES}

1. Brasil. Ministério da Saúde; Instituto Nacional de Câncer José Alencar Gomes da Silva. Estimativa 2012. Incidência de Câncer no Brasil [Internet]. Rio de Janeiro; 2011 [citado 2013 jul. 25]. Disponível em: http://portal.saude.sp.gov.br/resources/ ses/perfil/gestor/homepage/estimativas-de-incidenciade-cancer-2012/estimativas_incidencia_cancer_2012.pdf

2. Cecílio SG, Sales JB, Pereira NPA, Maia LLQGN. A visão do companheiro da mulher com histórico de câncer de mama. REME Rev Min Enferm. 2013;17(1):23-31.

3. Ramos BF, Lustosa MA. Câncer de mama feminino e psicologia. Rev SBPH. 2009;12(1):85-97.

4. Brasil. Ministério da Saúde; Instituto Nacional de Câncer. Controle do câncer de mama: documento de consenso. Rio de Janeiro; 2004.

5. Biffi RG, Mamede MV. Suporte social na reabilitação da muIher mastectomizada: o papel do parceiro sexual. Rev Esc Enferm USP. 2004;38(3):262-9.

6. Ferreira CB, Almeida AM, Rasera EF. Sentidos do diagnóstico por câncer de mama feminino para casais que vivenciaram. Interface Comum Saúde Educ. 2008;12(27):863-71.

7. Santos AM, Koch HA. A participação dos companheiros no diagnóstico e no tratamento do câncer de mama de suas muIheres. Rev Bras Mastologia. 2006;16(4):150-5.

8. Benefield LE. Implementing evidence-based pratice in home care. Home Healthc Nurse. 2003;21(12):804-11.

9. Polit DF, Beck CT. Essentials of nursing research: appraising evidence for nursing practice. Philadelphia: Lippincott Williams \& Wilkins; 2006.

10. Ganong LH. Integrative reviews of nursing research. Res Nurs Health. 1987;10(1):1-11.

11. Ursi ES, Galvão CM. Prevenção de lesões de pele no perioperatório: revisão integrativa da literatura. Rev Latino Am Enferm. 2006;14(1):124-31.
Integrative review studies are relevant for the grouping and synthesis of knowledge, and for bringing subsidies for the evidence-based practice, the care in nursing stands out. The results derived from this study provided a scientific basis for the practice and improvement of care.

Finally, the importance of developing new studies is emphasized, for a deeper understanding of the experience of spouses who go through the breast cancer of their wives, and for seeking the development of care strategies for this specific group.

12. Hoga LAK, Melo DS, Dias AF. Psychosocial perspectives of the partners of breast cancer patients treated with a mastectomy. Cancer Nurs. 2008;31(4):318-25.

13. Zahlis EH, Lewis FM. Coming to grips with breast cancer: the spouse's experience with his wife's first six months. J Psychosoc Oncol. 2010;28(1):79-97.

14. Dugglebly W, Bally J, Cooper D, Doell H, Thomas R. Engaging hope: the experiences of male spouses of women with breast cancer. Oncol Nurs Forum. 2012;39(4):400-6.

15. Hilton BA, Crawford JA, Tarko MA. Men's perspectives on individual and family coping with their wives' breast cancer and chemotherapy. West J Nursing Res. 2000;22(4):438-59.

16. Nasiri A, Teleghani F, Irajpour A. Men's sexual issues after breast cancer in their wives: a qualitative study. Cancer Nurs. 2012;35(3):236-44.

17. Silva TBC, Santos MCL, Almeida AM, Fernandes AFC. The perception of mastectomized women's partners regarding life after surgery. Rev Esc Enferm USP. 2010;44(1):113-9.

18. Pavão ZM. Pesquisa prática: seus principais instrumentos. Rev Diálogo Educ. 2001;2(4):85-94.

19. Labov $W$. The transformation of experience in narrative syntax. In: Labov W. Language in the inner city: studies in the black english vernacular. Oxford: Blackwell; 1977. p. 354-96.

20. Amiralian MLTM. Deficiências: um novo olhar: contribuições a partir da psicanálise winnicottiana. Estilos Clin. 2003;8(15):94-111.

21. Dantas CC, Leite JL, Lima SBS, Stipp MAC. Teoria fundamentada nos dados: aspectos conceituais e operacionais: metodologia possível de ser aplicada na pesquisa em enfermagem. Rev Latino Am Enferm. 2009;17(4):573-9.

22. Funghetto SS, Terra MG, Wolff LR. Mulher portadora de câncer de mama: percepção sobre a doença, família e sociedade. Rev Bras Enferm. 2003;56(5):528-32. 
23. Ferreira MLSM, Franco CB, Queiroz FC. Construindo o significado da mastectomia: experiência de mulheres no pósoperatório. Rev Ciênc Med (Campinas). 2002;11(1):47-54.

24. Cavalcanti M. Sexualidade humana: caminhos e descamin hos. Rev Bras Sex Hum. 1997;8(1):104-15.

25. Bielemann VLM. A família cuidando do ser humano com câncer e sentido a experiência. Rev Bras Enferm. 2003;56(2):133-7.
26. Melo EM, Silva RM, Almeida AM, Carvalho Fernádez AF, Rego CDM. Comportamentos da família diante do diagnostico de câncer de mama. Enferm Global [Internet]. 2007 [citado 2013 out. 22];(10). Disponível em: http://revistas. um.es/eglobal/article/viewFile/237/227

27. Ell K, Nishimoto R, Mantell J, Hamovitch M. Longitudinal analysis of psychological adaptation among family members of patients with cancer. J Psychosom Res. 1988;32(4-5):429-38. 